\title{
Cidade aberta, sem muralhas. A religião luso-brasileira na literatura de viagem (séculos XVIII-XIX) ${ }^{1}$
}

Open city, without walls. The Portuguese-Brazilian religion in the travel literature (XVIII-XIX centuries)

\section{Amilcar TORRÃO FILHO}

Resumo: A partir de finais do século XVIII e início do século XIX, um grande número de viajantes britânicos e franceses aportaram no Brasil, interessados em suas riquezas naturais e desejosos por conhecimento sobre a sociedade luso-brasileira. Um dos seus principais interesses era o conhecimento das práticas religiosas dos brasileiros que servia, tanto para católicos franceses quanto para protestantes britânicos, como um índice de civilidade alcançado por nossa sociedade. Suas descrições tratarão, assim, das igrejas, sua composição arquitetônica e obras sacras, das missas, procissões e festas religiosas, das obras de caridade, do clero católico, dos sacramentos como casamentos e batizados, enterros, etc. Nestas descrições estão colocadas interpretações da sociedade luso-brasileira, as possibilidades de desenvolvimento do novo Império brasileiro e o caráter do catolicismo português transplantado para a América.

Palavras-chave: Literatura de Viagem; Religiosidade; Viajantes; Retórica da Viagem.

Abstract: From the end of the XVIII century and beginning of the XIX century, a large number of British and French travelers docked in Brazil, interested in her natural riches and keen on knowledge about the Portuguese-Brazilian society. One of their main interests was the knowlege of the religious practices of the Brazilians who served to French Catholics as well to British protestants, as an index of civility reached by our society. In this way, their descriptions will be about the churches, their architectural construction and holy works, masses, processions and religious festivals, charitable works, the Catholic clergy, the sacraments such as wedding and baptism cerimonies, burials etc. Interpretations of the Portuguese-Brazilian society are included in these descriptions. The possibilities of development of the new Brazilian empire and the character of the Portuguese Catholicism transplanted to America.

Keywords: Travel Literature; Religiousness; Travelers; Travel Rhetoric.

Vários autores dedicaram-se a instruir o olhar dos viajantes, desde o Renascimento, educandoos para a observação útil da realidade. A literatura de viagem sempre operou um exercício de alteridade, no qual se buscava a compreensão do mundo e de sua diversidade. Uma das formas privilegiadas do reconhecimento da alteridade era a observação das práticas religiosas dos povos visitados, que poderia revelar tanto dos grupos humanos desconhecidos, dos chamados selvagens, como de outros povos e nações que partilhassem ou não a mesma religião do viajante-narrador. Em 1783, Constantin-François de Chasseboeuf, conde de Volney, empreendeu uma das viagens mais célebres da história, à Síria e ao Egito, que inspiraria Napoleão a invadir o país africano numa enorme e igualmente célebre expedição, observado ao pé das pirâmides por séculos de história. Embora seja muito citado por suas Questions de statistique à l'usage des voyageurs, conhecidas instruções que propunham um novo método para a viagem, dando-lhe um caráter mais claramente

\footnotetext{
- Professor Doutor - Departamento de História - PUC-SP - Pontifícia Universidade Católica de São Paulo - Rua Monte Alegre, 984, CEP: 05014-901, São Paulo, São Paulo, Brasil. E-mail: amilcartorrao@uol.com.br
} 
ligado ao conhecimento científico da época, foi na viagem citada que este método foi concebido e aplicado pela primeira vez, vindo a se tornar uma referência obrigatória a todo viajante daí por diante. Volney, consciente de que a viagem era um dos mais eficazes modos de "ornar o espírito e de formar o julgamento", decide por um "teatro" inusitado para a sua formação (VOLNEY, 1787, v. 1, p.iii). "Meu país e os estados vizinhos", diz ele, "me pareceram muito conhecidos, ou muito fáceis de conhecer". A América nascente e seus selvagens "me tentaram"; “outras ideias", afirma, fizeram com que se decidisse pela Ásia, mais especificamente Síria e Egito, pela dupla relação do que "eles já foram outrora e do que eles são hoje em dia”, parecendo-lhe um campo mais próprio para "as observações políticas e morais às quais desejava ocupar-me”. Pois seriam ali, nestes locais, que teria nascido a maior parte das "opiniões que nos governam", das ideias religiosas que influenciaram tão "poderosamente a nossa moral pública e particular, sobre nossas leis, sobretudo sobre nosso estado social" (VOLNEY, 1787, v. 1, p.iv). No berço das religiões do Livro, Volney buscava conhecer a origem das instituições ocidentais que governavam a Europa, por isso a observação das práticas e crenças religiosas estará no centro de seu método apodêmico (Cf. TORRÃO FILHO, 2008, p.1-3; e 2005, p.139).

Muitas instruções de viagem, comuns no século XVIII, ensinavam aos viajantes como observar a religião para o entendimento de uma dada sociedade. Josiah Tucker (1713-1799), escritor de obras políticas, sobre economia, a situação das colônias americanas e a emancipação de minorias religiosas como os judeus, acreditava que a comparação entre nações era algo fundamental para o conhecimento e o gerenciamento da sociedade, o que fica claro em uma de suas obras mais conhecidas, A Brief Essay on the Advantages and Disadvantages, which Respectively Attend France and Great Britain, with regard to Trade, de 1749. Seu Instructions for Travellers é de 1758 e inicia-se como um plano para o aprimoramento moral e político na Teoria do Comércio e Impostos, por meio da viagem (TUCKER, 1758, p.1). O deão Tucker tem em mente um tipo específico de viajante. Geralmente, diz ele, uma pessoa viaja com um ou mais destes objetivos: fazer coleções de objetos curiosos, como filósofos naturais, apreciadores de arte [virtuosos] ou antiquários; para aperfeiçoar-se em pintura, estatuária, arquitetura ou música; para obter a reputação de ser um homem de Vertù e de gosto elegante; para adquirir ares estrangeiros, e adornar suas "queridas pessoas" de roupas finas e novas modas, e sua conversação de novas frases; ou ainda, para extirpar preconceitos locais e adquirir esta "visão alargada e imparcial do homem e das coisas", que não pode ser adquirido em um único país. Este último objetivo é o mais adequado a um viajante moderno, a quem se destinam suas instruções (TUCKER, 1758, p.1).

Para este autor, a viagem é um método de estudo da sociedade, não apenas do mundo natural ou dos homens "selvagens". Ela não serve exatamente para adquirir os rudimentos do conhecimento, mas é uma oportunidade para "fazer uma judiciosa aplicação de conhecimentos 
precedentes" (TUCKER, 1758, p.6). As sociedades do mundo são, assim, laboratórios nos quais o viajante pode testar as suas teorias e o seu conhecimento prévio, por isso a necessidade de preparação do viajante, para a qual Tucker apresenta uma selecionada biblioteca de textos sobre religião, ética, lei, governança, peculiaridades da Constituição inglesa, estabelecimento da Igreja na Inglaterra e tolerância religiosa, política externa, comércio e impostos. Os temas de sua biblioteca deixam clara a sua teoria.

Seu objetivo é descrever os efeitos e consequências dos vários sistemas de religião, governo e comércio no mundo, e como eles operam "em povos diferentes, ou no mesmo povo em diferentes períodos". Aborda ainda como estes povos aumentam ou contraem os "poderes ativos da Natureza humana, ou se eles tornam esses poderes mais úteis, ou perniciosos à Sociedade" (TUCKER, 1758, p.4-5). Inicia com a religião, pois esta é algo que o viajante deve ter muito claro antes de sua partida, pois se ele sai de seu país sem firmeza em seus princípios religiosos, corre o risco de voltar sem nenhum ou converter-se a uma má religião, ou seja, tornar-se um papista. Pois o objetivo da viagem não é que ele conheça novas religiões, mas que o contato com elas reforce as suas convicções protestantes por meio da comparação e o reconhecimento das suas maiores qualidades em relação às demais, fazendo-o "indiferente a todas elas", sobretudo os "artifícios e falsidades da Igreja de Roma", que podem tentá-lo em algum momento (TUCKER, 1758, p.7-8). Vemos que a viagem serve em Tucker para consolidar um conhecimento prévio e as convicções religiosas, não exatamente para propiciar uma comparação e, dela, uma síntese que corresponda a um novo conhecimento. A viagem confirma, reforça e exemplifica a teoria daí a importância das leituras prévias, que devem instrumentalizar o olhar do viajante para uma compreensão adequada do mundo. Parte das instruções de Tucker se ocupa da discussão desta "biblioteca", que aqui não tem mais o caráter fugidio de uma memória, mas a força prescritiva de um modelo.

Segundo o autor, próximos da religião, e fazendo parte dela, embora nem sempre considerados assim, estão a Ética, a Lei Civil e a Governança em geral. Pois se trata de formar os futuros legisladores da nação e esta instrução, assim como a anterior, dá sua própria conclusão em seu enunciado: Tucker pode considerar que seus jovens viajantes são legisladores em potencial porque "numa Constituição como a nossa", diz o autor, não é improvável que estes jovens, um dia, venham a participar da produção das leis "pelo Bem de seu País”. Sendo assim, ele deve conhecer alguma coisa de sua natureza e do espírito da Constituição britânica (TUCKER, 1758, p.10-11). Ao contrário de outras nações, e a viagem serve para ensinar isso ao jovem educando, "cada Criatura é um Político; e formou em sua própria Mente o melhor Sistema igualmente para a Paz e para a Guerra" (TUCKER, 1758, p.66). Ao adquirir um conhecimento adequado das leis britânicas, o futuro legislador pode então compará-los com os dos demais países que venha a visitar, e em seu retorno, formar um "Juízo verdadeiro" de suas próprias leis, sabendo quais são mais ou menos 
adequadas (TUCKER, 1758, p.11). Diferentemente da religião, com relação às leis e à governança, Tucker reconhece a possibilidade de que o viajante encontre exemplos mais adequados em outras nações, que possam ser aproveitados pelos ingleses.

$\mathrm{O}$ artigo seguinte trata do estabelecimento legal da Igreja na Inglaterra e da tolerância religiosa. Um viajante de "educação liberal", ao conhecer outros países, deve ter claro como a Igreja se estabelece legalmente e em que medida são tolerados aqueles, cujas consciências não seguem a maioria nacional (TUCKER, 1758, p.12). Esta educação do olhar, dos sentidos e da mente deve fazer do viajante um observador atento, prevenido contra as "opiniões equivocadas do Populacho desvairado" (TUCKER, 1758, p.32), pois dele depende a afirmação das virtudes inglesas e a correção dos caminhos errados. Tucker reconhece que as questões são muitas e os temas demasiado variados para que possam ser alvo da atenção de cada viajante. Portanto, um viajante judicioso deve atentar ao que seja realmente "singular, curioso ou extraordinário", ao que deverá dar maior atenção. As questões, então, servirão para fixar a sua atenção no que seja notável, no que possa ilustrar ou esclarecer pontos importantes dos temas observados, permitindo que "aperfeiçoe seu Raciocínio, ordene seus Pensamentos e Idéias em sua Ordem conveniente" (TUCKER, 1758, p.2223). Assim, se a Inglaterra é uma nação livre, na qual bens e riquezas adquiridos pelo comércio não são uma desonra, onde a propriedade é resguardada das prerrogativas de príncipes ou nobres e onde qualquer pessoa pode ostentar sua fortuna sem ser taxado por talha ou capitação (TUCKER, 1758, p.39), é natural que o que seja observado em outros países considere o tempo quando esse sistema não era utilizado. Dessa forma serão ilustradas as desvantagens que isso acarretava ao país em questão, quase sempre mais pobre do que a Inglaterra, onde essa pobreza poderia ser explicada pelo mau uso dos recursos do sistema. O mesmo para as nações católicas, nas quais as suas mistificações deveriam ser destacadas para fortalecer a relação de harmonia da religião com o Estado e a sociedade na Inglaterra. Por exemplo, deveria o viajante atentar nos países papistas qual a proporção de feriados e procissões "pomposas", tornadas supérfluas na Inglaterra depois da "feliz Reforma”, e quais as suas consequências - pois é um dado indiscutível que haja consequências sobre a indústria e a moral do povo. Uma das consequências, que deveria ser notada, era a quantidade de ordens religiosas, e se elas inculcavam no povo o celibato e uma vida monástica e solitária, preferentemente a uma "vida ativa e industriosa" (TUCKER, 1758, p.84-85).

Dessa destacada harmonia entre religião e Estado, resulta a tolerância de que tratava Tucker no início de seu texto, que é inerente, segundo ele, aos princípios da religião protestante, fundada no "direito ao julgamento pessoal", sem o qual, acrescenta, os primeiros reformadores não poderiam justificar sua separação da Igreja de Roma (TUCKER, 1758, p.83). Se a viagem a países católicos serve para afastar o jovem da idolatria bárbara da igreja romana, a visita a um país protestante como a Holanda pode servir para renovar as qualidades intrínsecas da reforma, que porventura possam 
estar esquecidas na Inglaterra. Tucker, habilmente, argumenta que os holandeses foram os primeiros a incorporar a tolerância religiosa à sua constituição civil, ainda que seus motivos tenham sido mais comerciais do que religiosos. A insistência na afirmação de que esta doutrina era adequada às leis civis e às normas religiosas da Inglaterra e a menção à Holanda, faz supor que Tucker esteja argumentando que esta tolerância precisasse ser recordada por meio dos exemplos que poderiam vir de fora, mas que representassem um retorno às raízes verdadeiras da Grã-Bretanha, que poderiam ser questionadas, ainda que fosse por "algumas poucas pessoas preconceituosas, porventura de um temperamento malevolente", consideradas tão insignificantes que não mereceriam a atenção do público (TUCKER, 1758, p.84). A apologia à Grã-Bretanha, neste autor, às vezes sutilmente se transforma em crítica. Essa instrução mostra bem como a viagem é uma rota pré-traçada por uma teoria bem estabelecida, mas que não deixa também de ser um instrumento de crítica e questionamento da própria sociedade; ainda que a partir de pressupostos claros e definidos.

No século XIX, as instruções de viagem se destinam a um novo tipo de viajante, o viajante pitoresco, que busca em povos exóticos um conhecimento social e político por meio de imagens e textos agradáveis, de interesse do grande público ávido por novidades. O coronel Julian Jackson destaca a importância que se deve dar, num livro de viagem, aos dados sobre a população, referentes a sua procedência, religião, língua, classe social e profissões, que devem servir para formar um "quadro do estado moral e físico do país” (JACKSON, 1845, p.217-218). Assim, especial atenção deve ser dada aos costumes, hábitos e princípios dessa população, pois o caráter moral de um país está intimamente conectado com a sua riqueza, religião, leis e clima. Os homens têm "costumes antes de ter leis, e estes costumes primitivos geralmente devem sua origem ao clima de um país e às ocupações de seus habitantes" (JACKSON, 1845, p.220-221). Há então uma relação natural entre povos não civilizados e seus hábitos morais, ainda presos às suas origens, enquanto os povos mais civilizados, ao contrário, modificam seus hábitos e "a natural e direta influência do clima e da ocupação é neutralizada por necessidades externas”. Por isso os hábitos dos selvagens são simples e facilmente identificáveis, enquanto os dos civilizados são "complexos, difíceis de compreender, frequentemente contraditórios, e sua origem obscura (JACKSON, 1845, p.221). Para Jackson a pureza destes hábitos e valores era mais bem entendida no campo, entre os camponeses, já que a civilização, "retirando o homem da simplicidade e pureza da natureza, tende a corromper sua moral"; sendo as grandes cidades os centros de civilização, proporcionalmente eram mais corruptas. No entanto, isso não quer dizer que não se deva ter atenção às cidades, muito pelo contrário: pois se os hábitos e valores morais são considerados bons nos grandes centros, presumese “que serão ainda melhores no campo (JACKSON, 1845, p.221). A cidade é, então, um índice de civilização de um país, ao mesmo tempo em que serve para medir também o seu grau de corruptibilidade e degradação. 
A arquitetura para o coronel Jackson é uma materialidade do caráter nacional de cada povo, por isso uma atenção especial deve ser dada a ela: numa nação influenciada por um particular sentimento de mesquinhez ou fantasia, encontramos uma arquitetura da nudez, em lugar de simplicidade, e da extravagância em lugar da beleza; um povo frívolo teria formosura até na arquitetura; verdadeira beleza e sublimidade seriam características de um povo "avançado em real grandeza"; um povo cruel e atrabiliário teria uma arquitetura lúgubre e melancólica, como os calabouços da inquisição ou os claustros dos monges trapistas (a referência a Portugal, Espanha e Itália é evidente); um povo econômico e calculista, não construiria nada mais além do necessário, cujos escassos monumentos seriam simples e sólidos (aqui também as questões já vem respondidas, o itinerário já vem dado e pronto). "Um povo realmente civilizado, com um sólido julgamento e um gosto purificado, terá edifícios de cada um destes caracteres de acordo com a conveniência de seus respectivos objetivos" (JACKSON, 1845, p.399).

É informado por estas teorias prévias que os viajantes irão observar as cidades luso-brasileiras e as práticas religiosas dos brasileiros, numa tentativa de compreender a sociedade formada deste lado do Atlântico, utilizando-as como referência para a compreensão de sua própria sociedade. Neste espelho de alteridade, a religião é um dos índices de civilidade que inserem o Brasil numa escala gradativa que indica as carências, para a maioria dos autores, de nossa sociedade. Ela é uma chave explicativa fundamental, porque explica como as nossas instituições foram formadas, já que o homem tem costumes antes de ter leis, como lembra o coronel Jackson, e estes costumes determinam as leis. Ao mesmo tempo as crenças e práticas religiosas dão uma dimensão do atraso e são uma das bases de um projeto político de regeneração, necessário para a construção na jovem nação.

\section{Cidade Aberta}

Cidade aberta, sem muralhas; tal é o homem sem autocontrole. Provérbios, 25:28.

As cidades sobre os montes, sobre locais elevados, tão preferidas pelos portugueses, com suas torres de igrejas pitorescas destacando-se na paisagem, não eram identificadas apenas ao teatro, ao domínio da ilusão e da aparência, mas também ao da idolatria. O Deuteronômio é muito claro: "Devereis destruir os lugares em que as nações que ireis conquistar tinham servido a seus deuses, sobre os altos montes, sobre as colinas e sob toda árvore verdejante" (DEUTERONÔMIO, 12, 2). É uma constante no Velho Testamento a identificação da idolatria, não a dos pagãos, mas a que incorriam os próprios israelitas, com suas oferendas e ritos realizados nos chamados lugares altos, cimos de montes onde se realizavam estas cerimônias ilegais. As citações poderiam ser inúmeras, 
fiquemos com outro trecho que trata de refletir a ruína do Reino de Israel: "Os israelitas proferiram palavras inconvenientes contra Iahweh seu Deus, construíram lugares altos em toda parte em que habitavam, desde as torres de vigia até as cidades fortificadas". Imitaram os israelitas, as nações que Iahweh havia expulsado da Terra Santa, prestaram "culto aos ídolos, embora Iahweh lhes tivesse dito: "Vós não fareis tal coisa'" (2REIS, 17, 9-12). Se a fonte de poder divino se encontra nas "alturas" do céu, as Escrituras advertem "contra a pretensão de conhecer as coisas 'altas"” (GINZBURG, 1989, p.98-99). A Bíblia é fonte privilegiada de imagens da literatura de viagem, "texto fantasma, mas tão presente" (NOTHOMB, 2004, p.63) na literatura e no pensamento; ela faz parte de uma "cultura compartilhada" entre o viajante e o leitor, e entre os diversos viajantes, católicos ou protestantes, e irrompe na narrativa, "evocando o lugar fundamental que ela ocupa no seu universo imaginário e o papel que ela desempenha em sua leitura do mundo"; e é por meio do texto sagrado que "os outros e a religião que eles praticam serão apreciados" (PAYET-MEURE, 2005$, p. 182$)^{2}$. As imagens pitorescas e tão representativas das cidades luso-brasileiras, com suas torres de igrejas e conventos destacadas na paisagem em meio a bosques, florestas e montanhas, revelam também espaços de idolatria e paganismo. Muitas vezes pensa-se que as imagens negativas da religiosidade brasileira seriam resultadas de uma visão protestante de viajantes britânicos, alemães ou norte-americanos. No entanto, veremos como o incômodo com estes rituais será comum a protestantes e católicos no mesmo grau de decepção e horror.

A viagem sempre esteve ligada à religião, tanto em sua forma de narrativa como de itinerário de peregrinação ${ }^{3}$, como do próprio ponto de vista do deslocamento e da religação que viagem e religião compartem; viajar significa separar-se dos entes queridos, da pátria, pressupõe um luto, mas também um retorno: no "deslocamento que lhe fundamenta, na distância que se percorre, no exílio que ela remata, reúne o outro e o mesmo" (LESTRINGANT, 2005, p.15). Vimos que para Josiah Tucker, dar atenção às formas e ritos religiosos dos países visitados era fundamental, não tanto para ter um conhecimento etnográfico destes locais, mas para fortalecer a própria, e verdadeira, crença. A viagem a países católicos, no caso dos protestantes britânicos, ou para nações "atrasadas", no caso de católicos franceses, obriga ao viajante uma atenção à alteridade diferente da visita a países islâmicos, ou a povos considerados "bárbaros" e fetichistas". Nestes locais, a diferença é evidente e clara; já em cidades como as luso-brasileiras, a alteridade está dentro de um mesmo esquema conceitual, com representações muito próximas, uma aparência de similitude. Daí advém um estranhamento ainda maior, pela proximidade deste universo simbólico que, ao mesmo tempo, o viajante não reconhece como sendo parte de seu repertório cultural.

O relato da Missionary Society, que esteve no Rio de Janeiro em 1796, deixa bem claro esse incômodo com os rituais católicos do Brasil. A sua capital parece, para eles, "exceder todos os locais papistas em matéria de religião". Em cada esquina se podia encontrar uma figura de Nosso 
Salvador e da Virgem Maria “colocada num nicho, ou uma espécie de armário, com uma cortina e janela de vidro". Pela noite, havia velas acendidas; e o pior, ao passar defronte a essas imagens, "as pessoas param para dirigir suas devoções, e por toda a noite a voz de suas cantorias para estas imagens pode ser ouvida". E até mesmo o mais pobre mendigo "faz negócio com a religião", carregando um crucifixo em seu peito, abençoa as pessoas que lhe cruzam o caminho, e "deve ser pago por essa benção assim como o papa" (MISSIONARY SOCIETY, 1799, p.33). Como missionários, é claro que o espetáculo da escravidão não lhes passa despercebido, escravos doentes pelas ruas, e a terrível imagem, sempre recorrente, do mercado de escravos. Mas a "idolatria" dos católicos luso-brasileiros parece atrair-lhes mais a indignação. Recebidos no palácio do governo, foram recepcionados pelo coronel comandante com toda a polidez, e por sua mulher, que foi "especialmente atenciosa com nossas esposas", diz o narrador. No entanto, diz ele, não puderam retribuir as gentilezas, especialmente

quando vimos suas arraigadas superstições, seus rosários e crucifixos pendurados em seus pescoços; e a cruz e seus santos estão nas esquinas de cada rua, e por fora de suas casas: às quais eles se inclinam reverentes e se persignam quando passam. Eles realmente parecem afundados na idolatria (MISSIONARY SOCIETY, 1799, p.35).

Nenhuma demonstração de cortesia pode superar, para estes missionários, os erros papistas destes católicos; certamente eles são considerados piores do que os "selvagens" dos mares do Sul, aos quais pretendiam converter em sua viagem.

Outra coisa que lhes chama a atenção, e de praticamente todo viajante que esteve em nossas cidades, são as procissões: com padres, freiras, carpideiras, "entrando em uma de suas catedrais", brilhando com seus candelabros acesos. As preces eram rezadas, e "coros cantavam, acompanhados por uma banda de músicos. A visão nos afligiu; contemplar esta pompa exterior de devoção, e não descobrir nenhum traço da imaculada religião de Jesus” (MISSIONARY SOCIETY, 1799, p.36). Descrições muito parecidas com as de James Cook, cujo curto espaço dedicado ao Rio de Janeiro, em sua primeira viagem de circunavegação, foi base de quase todos os visitantes que lhe seguiram. Para ele as igrejas da cidade eram muito bonitas, mas havia mais "ostentação religiosa [religious parade] neste lugar do que em qualquer dos países papistas da Europa”. Há procissões em todos os dias paroquiais, "com várias insígnias, todas esplêndidas e caras no mais alto grau”. E ainda se pede dinheiro e se faz orações "na esquina de cada cidade" (COOK, 1862: v. 1, p.14) ${ }^{4}$. Este será um dos lugares-comuns mais frequentes na narrativa de viagem, a superficialidade da fé brasileira, bem como de suas instituições, desprovidas de substância. E que chegará até a historiografia e os intérpretes do Brasil, e a Sérgio Buarque de Holanda, um dos primeiros a formular esta ideia de "uma religiosidade de superfície, menos atenta ao sentido íntimo das cerimônias do que ao colorido 
e à pompa exterior, quase carnal em seu apego ao concreto e em sua rancorosa incompreensão de toda verdadeira espiritualidade" (HOLANDA, 1988, p.111). Avaliação tão ou mais dura que a da Missionary Society, mas utilizando-se exatamente das mesmas palavras. Esta imagem da superficialidade, da aparência, eu já tive a oportunidade de observar que é uma das bases da descrição da cidade luso-brasileira, e esta aparência, da qual já tratei em relação à paisagem urbana, toma uma substância moral ainda maior com relação à religiosidade: aqui, o material e o moral estão irmanados, promovendo uma interpretação global da sociedade.

Não é a falta de devoção que incomoda aos viajantes, mas uma devoção mal posta, inadequada e muitas vezes anacrônica. Watkin Tench, em 1787, também tem sua atenção voltada aos nichos com santos em quase todas as esquinas, com imagens da Virgem. O zelo na devoção a estes locais, não pode deixar de causar "espanto ao estrangeiro". A maior parte dos habitantes, diz Tench, "parece não ter outra ocupação, a não ser a de retribuir visitas e ir à igreja, ocasiões em que você os vê ricamente vestidos" (TENCH, 1789, p.22-23). Ainda assim, a polícia da cidade, ou a sua administração, se ressentia destes hábitos de devoção exterior, que impediam o progresso de ações mais ilustradas, sendo os ouvidos dos estrangeiros "felicitados pelo repicar dos sinos dos conventos, e seus olhos saudados pelas procissões dos devotos, cuja adoração e leviandade parecem andar no mesmo passo, e suceder uma à outra alternadamente" (TENCH, 1789, p.28).

John White é mais prolixo em sua descrição da procissão assistida na cidade do Rio de Janeiro pela armada do governador Phillip. Pessoas de todas as classes, a pé, a cavalo ou em carruagens formavam uma multidão em direção à Igreja da Glória, em frente da qual paravam para rezar e cantar hinos religiosos. No caminho de volta da procissão, White percebe uma pequena igreja numa rua secundária, "ricamente ornamentada e elegantemente iluminada" na qual homens, mulheres e crianças disputavam a entrada. Entrando na pequena igreja, toda a satisfação que ele tirou do fato de ser "espremido e acotovelado", foi ver os fiéis caírem de joelhos, e rezarem "com mais fervor, em aparência, do que em real devoção". Eram distribuídos rosários consagrados, e as ruas estavam cheias de vendedores ambulantes de artigos religiosos, além de muitos músicos e cantores, que se esforçavam em agradar a audiência, mas que não tiveram muito sucesso com White. Às dez horas, os entretenimentos do dia foram encerrados com "fogos e foguetes, dos quais os portugueses parecem gostar muito" (WHITE, 1790, p.50-53). Não apenas uma fé de aparência, mas uma inadequação incompreensível, do ponto de vista do viajante, que não entende a relação que estabelece a procissão entre devoção, divertimento e comércio. O diagnóstico dessa inadequação se dá mais, como está sugerido no texto de Josiah Tucker que discuti no capítulo anterior, num conhecimento prévio da idolatria dos papistas do que na experiência vivida na cerimônia religiosa. São os livros que conferem à religiosidade do catolicismo brasileiro o seu caráter de "superfície" e 
de "rancorosa incompreensão de toda verdadeira espiritualidade", não um conhecimento adquirido por meio dos sentidos.

Observando a procissão de Nossa Senhora da Conceição da Praia em Salvador, Lindley se surpreende também com a veneração que as imagens "despertam no povo, que geralmente as adora de maneira devota e abjeta, como se contivessem a essência da própria Divindade, descendida na ocasião, in propria persona" (LINDLEY, 1805, p.92). No dia de Reis, ou quando se comemora o dia em que "se supõe" que os três Reis Magos visitaram e adoraram a Cristo, músicos ambulantes cruzam as ruas em grupos, "indo de casa em casa, sem a menor cerimônia, e fazendo em cada uma um bárbaro tumulto; e depois de repetirem as mesmas tolas formalidades, seguem adiante para importunar o próximo habitante", o que se segue por toda a noite; a multidão participa deste "rude regozijo, e parece desfrutar da cena". Muito mais do que uma comemoração cristã, pareceu ao contrabandista "um carnaval italiano, cheio de confusão, mas sem o espírito picante e o vivo interesse que inspira esta festa" (LINDLEY, 1805, p.123-124). Ele não vê relação entre a festividade e a forma tão curiosa de preservar a memória destes Reis; há uma inadequação tanto da festividade, uma incompreensão da verdadeira tradição cristã, quanto da forma da comemoração desta tradição; trata-se, diz ele, de "obscuros vestígios do século XIV que ainda não foram abolidos" (LINDLEY, 1805, p.123-124). Solidificam-se aqui mais duas imagens a juntarmos à religiosidade de aparência: o desvirtuamento da verdadeira tradição e os resquícios de uma religiosidade atrasada e obscura.

John Turnbull tem uma impressão mais condescendente da religião católica no Brasil em sua breve estada em Salvador, em 1800, ainda que esta condescendência revele, para ele mesmo, a superioridade de sua fé reformada. As igrejas da cidade lhe pareceram bastante bonitas e bem decoradas, e lotadas de fiéis de todas as dignidades, e a devoção tão sincera, que mesmo sendo protestantes, "e sem nenhuma predileção por sua santidade o papa", isso não deixa de lhes dar uma boa impressão (TURNBULL, 1805, v. 1, p.23). Assiste a uma cerimônia na Catedral da cidade, num domingo de festa, com sermão proferido pelo bispo, que ele considera eloquente e vigoroso, ainda que um pouco exagerado, contra os "vícios e impiedades". Em seguida, a imagem de Nossa Senhora e do príncipe do Brasil são levadas em procissão pelas ruas da cidade, reverenciadas pelas mulheres, de seus balcões: "Um espetáculo teatral de forma alguma desagradável, se o zelo de uma religião equivocada pode ser admitido como escusa pelos seus erros" (TURNBULL, 1805, v. 1, p.24-25). Turnbull não duvida, ao contrário de muitos outros viajantes, da sinceridade da fé católica dos luso-brasileiros, ainda que a ideia de aparência esteja clara na identificação da festividade com um espetáculo teatral; entretanto, esta sinceridade serve apenas para perdoar os seus erros, ainda que ao final de sua digressão ele assuma, para si mesmo e para o leitor, a dúvida em relação à 
possibilidade desse perdão: ele é possível se pudermos considerar a autenticidade de um sentimento equivocado como um paliativo para o erro da doutrina.

Luccock também apontou aspectos da religiosidade dos luso-brasileiros e seus preconceitos, que interferiam na organização da própria sociedade, impedindo-lhes, por exemplo, uma dieta mais saudável. Observa ele que o povo costuma se alimentar de carne de porco com muita avidez, "como se o encantassem todas as oportunidades de demonstrar que eles não são nem judeus nem maometanos. Duvido, no entanto, de que tal como é produzido no Brasil, seja uma dieta não só desejável como saudável” (LUCCOCK, 1820, p.44). Já o carneiro não é consumido porque dizem que "não é comida própria de cristão", por ter sido "o Cordeiro Divino que tomou consigo os pecados do mundo" (LUCCOCK, 1820, p.44). Hábitos atrasados, religiosidade "superficial", estas crenças menos do que religiosas eram superstições que pouco serviam na necessária obra de civilização dos luso-brasileiros, não mais na fé cristã, mas sobretudo na formação de bons e úteis cidadãos.

A religião esteve na base da conquista do Brasil, na conversão dos naturais à religião cristã, recorda Barrow, sendo assim, isso propiciou enorme riqueza às igrejas e conventos. Mas fosse qual fosse o zelo do clero para executar esse projeto, diz autor, "ele há muito tempo deu lugar à indolência e ao luxo da vida monástica". O zelo transformou-se em uma prudência em conservar "um exterior de devoção observando de uma maneira extraordinariamente pontual as cerimônias religiosas que espantam o olhar do vulgo". Esta acomodação que acomete o clero luso-brasileiro faz com que eles "relaxem em sua moral e em sua conversação, e eles não são muito inclinados à severidade com relação aos laicos" (BARROW, 1807, v. 1, p.131-132). Sendo ainda muito influentes, sua relaxação de costumes só pode ter uma função deletéria na sociedade. Mas esta relaxação não está sozinha na desagregação desta sociedade em formação, o ritual ultrapassado, a riqueza inutilizada no luxo das igrejas e dos ornamentos das procissões, com jóias cravejadas de topázios, diamantes, ouro e prata, fornecidos pela igreja ou pelos moradores mais ricos, dos quais poucos eram, diz ironicamente Barrow, "ímpios o suficiente para recusar seus diamantes, quando a Virgem é exposta aos olhares do público". Há também o controle sobre o cotidiano dos habitantes da cidade, obrigados a parar sua marcha a cada repique dos sinos. Ou nas festas, quando "os foguetes ou os petardos estouram no ar, os olhares se voltam naturalmente para as alturas nas quais as igrejas e os mosteiros são construídos" (BARROW, 1807, v. 1, p.133). Edificada sobre os lugares altos da América, nem o mais contumaz pecador será ímpio o suficiente para não merecer nela um lugar, para não merecer dela o seu perdão em troca de ouro ou diamantes.

Como já havia observado a diferença de religião não implica em imagens distintas da religiosidade brasileira. Franceses católicos pintam as cerimônias religiosas praticamente com as mesmas cores que seus contemporâneos protestantes, talvez com uma pequena diferença, ao 
insistirem menos na "idolatria" e no culto às imagens, pecado do qual, afinal, poderiam também ser acusados. Na província das Minas Gerais, Saint-Hilaire vê como fenômenos correlatos tanto a venalidade das autoridades de justiça como a simonia entre os eclesiásticos. Diz ter travado conhecimento com um padre de um pequeno vilarejo, que lhe pareceu "esclarecido e aplicado aos seus deveres", que lhe declarou ser de idade avançada e, necessitando repouso, desejava deixar sua paróquia por um canonicato. Numa segunda visita, levando a conversação para a cidade do Rio de Janeiro, declarou conhecer certa pessoa de importância na capital. Imediatamente o padre pediu-lhe que intercedesse com ele por seu canonicato, afirmando que se fosse necessário dar-lhe dinheiro, ele o faria. "Mas é uma simonia o que o senhor me propõe, senhor padre!", exclama com surpresa e indignação Saint-Hilaire; a resposta é que ele sabia ser uma simonia, mas esta era um uso comum na terra, e sem ela "não podemos fazer nada", declara o padre (SAINT-HILAIRE, 1830, v. 1, p.174175). A corrupção da igreja é assim, paralela à corrupção da sociedade, e a igreja enquanto instituição e a religião não pareciam capazes de resolver. E para Lavollée, os males da religião brasileira são correlatos à forma anacrônica de organização do Estado brasileiro. Para ele, a monarquia brasileira, embora constitucional, havia conservado o cerimonial e as formas das monarquias absolutas, e com elas, uma "religião de ostentação [parade], que em certos dias conduziam ao pé dos altares enormes dragonas e uniformes brilhantes chamados a apresentar periodicamente os sinais públicos de uma piedade fingida [de commande]". Nesta interpretação, tanto o Estado brasileiro quanto sua religião são apenas formas de uma falsa civilidade e de uma fé de aparências. O anacronismo volta à cena, na comparação das procissões com as festas religiosas da Idade Média, e não é por acaso a comparação com a Idade das Trevas, pela profusão de imagens e confrarias. A diferença é que na Idade Média, "existia ainda a fé, que cobria de um sentimento respeitável o que poderia existir de estranho e às vezes grotesco nos acessórios e ornamentos da cerimônia”. Já numa cidade como o Rio, uma procissão deste tipo "era um anacronismo, um velho costume muito mais do que uma solenidade devota"; a religião, numa situação como esta, era transformada em “espetáculo"” (LAVOLLÉE, 1852, p.42-43).

Na verdade, igreja e Estado atrapalhavam a lenta marcha da civilização no Brasil. Para SaintHilaire havia demasiadas igrejas, o menor vilarejo "possui às vezes cinco ou seis templos; uma confraria mal tem algum fundo e começa a construir uma igreja, sem sonhar como ela acabará". Iniciada a construção e acabados os fundos, esfriado o zelo dos fiéis, "o edifício não se acaba nunca, ou então se decora o seu interior, e os muros caem em ruína”. Não era incomum que os viajantes se espantassem com as prematuras ruínas de um país tão jovem, tão pouco pitorescas, pois não indicavam o tempo passado, a civilização em sua marcha, mas apenas a incúria. Constroem-se, diz ele, "templos sem necessidade, fazem-se despesas insanas para celebrar festas patronais em cerimônias quase pagãs", no entanto, ninguém sonha jamais “formar estabelecimentos de caridade, 
fundar hospitais, escolas gratuitas, etc., etc. Não é nem mesmo uma piedade mal entendida que devemos acusar por tais abusos; sua origem está fundamentalmente na vaidade"; vaidade que pode ainda ser observada nas disputas entre as confrarias, nos privilégios que almejam por meio de "vãs prodigalidades" (SAINT-HILAIRE, 1830, v. 1, p.175). Koster observa o mesmo com relação ao Recife, uma escolha equivocada das prioridades; afirma que o hospital de São Lázaro, na capital pernambucana era "negligenciado", embora os pacientes ainda fossem admitidos e, como outros estabelecimentos do gênero, estavam todos “em estado muito miserável”. É estranho, diz ele, que "belas igrejas sejam construídas enquanto muitos indivíduos sofrem até a morte por falta de um edifício conveniente para abrigá-los" (KOSTER, 1816, p.34).

Os altos custos dos casamentos, cobrados pelas igrejas, impediam também que a moral se desenvolvesse no país, que já tinha tanta "repugnância em contrair uniões legítimas”, onde seria essencial "para o Estado e para a moral pública que elas fossem encorajadas". Entretanto, “os indigentes são, por assim dizer, arrastados por sua falta de meios, a viver em uma culpável desordem” (SAINT-HILAIRE, 1830, v. 1, p.176-177). Culpável, note-se, muito mais do ponto de vista do Estado e da Igreja, do que dos homens miseráveis, sem meios para se casar corretamente. O grande mal será, então, um descolamento das instituições da Igreja, do seu cerimonial, da verdadeira substância da religião, uma "indiferença com relação aos deveres mais essenciais"; esta "apatia”, que Saint-Hilaire credita muitas vezes a uma herança indígena, faz com que a religião, aqui, "permaneça sem moral, e não se conserve dela senão as práticas exteriores" (SAINTHILAIRE, 1830, v. 1, p.174-179). Os deveres dos laicos, diz ele, se resumem "a assistir a missa aos domingos e dias de festa, e a se confessar na Páscoa". Ir à igreja com um livro, "é se expor ao ridículo", e na província de Minas, se existem exemplares da Escritura, ele só pôde ver dois; e os padres não têm muito mais obrigações do que as dos próprios fiéis: "Eles só dizem uma missa baixa aos domingos", e ainda podem escolher, "ao seu capricho", em que igreja fazê-lo". Não há nunca uma leitura do Evangelho na missa, não há nenhum tipo de instrução religiosa, padres só visitam os doentes para administrar-lhes a extrema-unção não catequizam as crianças e, o mais incrível, não as examinam "para saber se são suficientemente instruídos para serem admitidos na primeira comunhão" (SAINT-HILAIRE, 1830, v. 1, p.179-180). Com tão poucas obrigações não espanta que os padres se dediquem a outras atividades, alheias à religião, como o comércio, ou a advocacia (SAINT-HILAIRE, 1830, v. 1, p.181).

E as cerimônias e festas religiosas possuem um caráter muitas vezes ao mesmo tempo ridículo e inadequado, como fica claro na anedota contada sobre o presépio de Barbacena. Saint-Hilaire explica a seu leitor a realização destes "espetáculos ridículos chamados presépios, onde se faz representar, por marionetes, cenas tiradas das Santas Escrituras”. A descrição é feita a partir do testemunho de um local, que os informa que os assistentes deveriam pagar para ver o espetáculo, o 
que faz com que desistam de vê-lo. O pagamento era feito com a passagem de um prato pela assistência, quando um companheiro dos organizadores era escolhido para colocar sua contribuição "antes do estrangeiro escolhido como vítima"; ele colocava uma quantia elevada para que o pobre viajante se constrangesse a não colocar menos. Como se não bastasse, o espetáculo era "frequentado principalmente por mulheres de má vida, não sendo, ao que parece, mais do que um ponto de encontro de deboche" (SAINT-HILAIRE, 1830, v. 1, p.123-124). Cerimônia deslocada e indecorosa pela inconveniência da teatralização ridícula das Escrituras, pela comercialização imoral dos temas santos e pela total decadência dos costumes e da moral, onde se deveria esperar recato e zelo religioso. A única solução seria uma reforma nas instituições, com uma seleção mais rigorosa dos eclesiásticos e a urgente catequese das crianças. O naturalista católico utiliza o mesmo aparato conceitual da protestante Missionary Society britânica, chegando praticamente ao mesmo diagnóstico das mazelas da religião no Brasil, que serão transferidas para a historiografia. As diferenças de doutrina não impedem a similitude da avaliação.

Le Dault vê na ornamentação das igrejas e da catedral da cidade do Pará, em sua materialidade, nos "quadros ruins" que as decoram, imagens do "fanatismo religioso do povo" que as frequenta. Nelas, "os milagres se operam a cada dia e custam muito caro; é o que percebemos pela riqueza das oferendas depositadas sobre os altares e os donativos enviados aos numerosos conventos" (LE DAULT, 1834, p.229). O navegador francês Barral, que visitou Santa Catarina em 1831, também observou o que considerava uma falta de decoro da religião praticada no Brasil. Os habitantes desta província seriam, em sua visão, provas vivas do fato de que todos "os povos ignorantes, simples ou corrompidos, sabem aliar os prazeres com as práticas austeras da religião". Como outras avaliações deste tipo, a premissa de Barral poderia identificar diversas práticas festivoreligiosas do Velho Mundo, mas no espelho da alteridade das narrativas de viagem, o repositório de "defeitos" e "máculas" constitui sempre um dado da descrição dos povos "exóticos". Seguindo Barral, sua narrativa acompanha a organização de uma novena em honra do santo protetor de uma família, cuja casa tornou-se ponto de encontro de toda a vila. O cômodo principal da casa foi decorado com um altar onde foi colocada a imagem do santo, tendo em seus braços o menino Jesus, "apesar do anacronismo"; o autor se espanta com esta imagem "anacrônica", que compõe o que os moradores "chamam de bom Jesus". São nomeados um presidente e uma presidente da novena "para fazer as honras da festa, isto é, para fazer por sua conta, as despesas indispensáveis de cachaça, da iluminação, dos fogos e dos petardos". Às oito horas, um petardo e um tiro de fuzil anunciam a abertura da cerimônia; as mulheres à medida que chegam se ajoelham diante do bom Jesus, enquanto os homens se sentam nos bancos. Sem se falar durante algum tempo os dois sexos, logo são propostos jogos e, apesar da reunião ter um objetivo religioso, "homens e moças fazem rondós, se abraçam e dançam fandangos". Em determinado momento, o presidente recorda o objeto 
da reunião, e "o recolhimento mais completo sucede às danças e aos cantos profanos; e parece querer-se expiar os prazeres aos quais nos permitimos, ficando mais de uma hora de joelhos recitando litanias". Em seguida, retomam as danças profanas, que duram grande parte da noite, e "cada um volta para a sua casa muito satisfeito de poder obter assim as boas graças dos santos do Paraíso" (BARRAL, 1833, p.341-342).

A contradição é clara, ainda que quase nunca indicada: as cidades luso-brasileiras são apresentadas, geralmente, como desprovidas dos mais elementares divertimentos; apesar disso, as festas religiosas, procissões e até esta animada novena, são frequentemente descritas sem que entrem na conta de divertimentos ou de vida social. Essa dificuldade de compreensão decorre de dois fatos muito bem apontados por Barral: o anacronismo destes divertimentos, ou das práticas litúrgicas do catolicismo luso-brasileiro e uma dificuldade em decifrar estas práticas híbridas, no limite entre o profano, o pagão e o religioso, ações deslocadas, sem lugar conveniente no universo simbólico do estrangeiro. Ouseley se espanta com os ex-votos pedindo proteção aos navios na capela da Boa Viagem, no Rio de Janeiro, onde viveu entre 1832 e 1844. Estranha a "adoção ou modificação de costumes pagãos", que representam a absorção pelo Catolicismo Romano de práticas da mitologia grega, como os ex-votos. "Por meio de uma simples transição, o altar gentio foi suplantado pelo de Roma". Um sistema de conversão que se não pode deixar de ser "repugnante aos sentimentos dos rígidos reformadores protestantes, não resulta pouco pitoresco e interessante àqueles que apreciam recordações clássicas”. Se por um lado ofendem a doutrina, estas práticas têm o mérito de divertir, pelo pitoresco, e educar, ao remeterem a um passado clássico e pagão, e a sua incorporação pelo catolicismo. É interessante, diz o autor, traçar nestes rituais, "à distância de tempo e espaço que separam a América do Sul do Olimpo de nossos estudos de escolares, estes obscuros reflexos da Grécia nos costumes Romanos” (OUSELEY, 1852, p.24).

Essa inadequação se transforma em paradoxo na descrição de Du Petit Thouars, que esteve no Rio de Janeiro em 1836. Chama-lhe a atenção, como a todos os viajantes, a frequência das procissões na cidade, mas a justificativa que ele dá para este fato é quase surpreendente. Elas são inúmeras e realizadas com "grande pompa", com a participação sempre de muita gente, "pois a população em geral, infelizmente muito depravada, e pouco religiosa, apoia-se muito na observação de formas exteriores de culto”. Elas são ainda, muito curiosas pelo grande número de ordens e confrarias que participam, além da "riqueza e variedade de costumes" (DU PETIT THOUARS, 1840, p.65). Chega a ser desconcertante a sua formulação: a depravação e irreligiosidade estão na base das cerimônias religiosas luso-brasileiras, verdadeira projeção de um mundo às avessas; paradoxo instigante, surpreendente, tão exótico quanto estas próprias cerimônias, e argumento que não deixou de ter certo fortúnio nas interpretações da sociedade brasileira. 
Desembarcado em Desterro, na ilha de Santa Catarina, Du Petit Thouars descreve cerimônia de forma bastante parecida àquela presenciada por Barral na mesma cidade; não mais uma novena, mas o enterro de uma criança morta logo após o batismo. Levado pela curiosidade, pois ele não pode deixar de imaginar que qualquer atividade na América será forçosamente curiosa e inversa do que se passa na Europa, ele vai à casa da família da criança morta, e se surpreende com o tom festivo da cerimônia, percebendo uma recepção numerosa. A casa estava ornada de folhagens misturadas com flores, havia um altar montado com a imagem de uma pequena criança, rodeada de círios e vasos de flores, descoberta e ricamente vestida; "sobre a cabeça estava posta uma coroa de perpétuas, e tinha nas mãos um buquê". Muitas mulheres vestidas de festa estavam sentadas ou ajoelhadas sobre esteiras, os homens fora da casa, por falta de espaço. Quando todos haviam chegado, começou-se a cantar e tocar guitarras, violões, tambores e, não sem surpresa, ao final todos passaram "a cantar, a rir e a beber". A explicação para isso era que, segundo "as crenças e costumes estabelecidos", a morte de uma criança que não tinha ainda atingido a idade da razão a transformava num anjo, e era costume "festejar esse acontecimento feliz por comemorações às quais eram convidados toda a família e todos os amigos" (DU PETIT THOUARS, 1840, p.83-84). Mais uma vez, o mundo invertido por uma crença anacrônica, uma festividade sem lugar, na qual uma desgraça se transforma em motivo de regozijo. Não está clara a forma como Du Petit Thouars chegou a esta cerimônia familiar, ainda que fosse pública, e não seria estranho ao gênero que ela tivesse sido escutada pelo viajante e contada como se fosse uma experiência pessoal. Entretanto, uma nota sua dá uma pista de que ele talvez tenha presenciado este enterro; ainda que sirva para reforçar a sua incompreensão desta "festividade" mórbida, é um momento, não muito comum, mas que por vezes emerge na narrativa, de certa empatia com o outro, um momento no qual houve um esforço por se aproximar do indivíduo com um pouco menos de teoria, ainda que com alguma. A pobre mãe da criança, diz ele, “estava alheia a esta festa; ela não podia se consolar da perda de um bem tão precioso, ela se abandonou à sua dor e vertia lágrimas abundantes; seu coração oprimido renegava uma parte desta felicidade cruel (DU PETIT THOUARS, 1840, p.84).

A “superstição" destas práticas anacrônicas se liga, em Debret, à preguiça. Para ele, o “temperamento sutil e os desejos ardentes" eram alimentos para esta superstição, sobretudo para um povo que vivia "num clima exagerado e, por isso, debilitante. Este excesso de imaginação, decorrente deste clima, "crescendo em sentido inverso de sua energia física, domina o resto de suas faculdades enervadas". Por isso, diz ele, é possível ver no Brasil "muitos homens, tornados preguiçosos em consequência da prostração de suas forças físicas, escolherem para a base de sua crença o fanatismo, meio mais fácil de justificar o estado de miséria em que se deixam estagnar por indolência". E para os menos indolentes, porém mais pobres, a única opção era ainda a devoção fanática, "na esperança de esconder um crime com a ajuda de um socorro divino ou, às vezes, 
alcançar uma injusta vingança". E esta indolência, seguindo a teoria de Debret, deveria ser resultado da herança da mistura dos europeus com a raça indígena, "vencida pela credulidade e civilizada tão somente à custa de mistificações misteriosas inventadas pelos missionários" (DEBRET, 1834-39: v. 3, p.39-40). Por isso as cerimônias religiosas introduzidas no Brasil pelos missionários teriam conservado à época, um caráter de "barbárie, isto é, de exagero necessário para surpreender a imaginação dos índios selvagens, apresentando-lhes imagens esculpidas e coloridas, sobretudo de uma proporção gigantesca" (DEBRET, 1834-39: v. 3, p.19). Na interpretação de Debret, e dos outros viajantes citados aqui, não importam as contradições ou diferenças, a explicação deve seguir o caminho traçado pela teoria previamente esboçada, na qual fanatismo e indolência são os termos necessários para a compreensão da sociedade formada no Brasil. Uma sociedade marcada pela superstição e pelo anacronismo de formas religiosas de aparência, que não compreendem a substância espiritual da religião, ideia presente seja entre os viajantes reformados ou católicos romanos, o que explica deste ponto de vista, todos os males destes condenados que vagam neste Éden tropical decaído que é a América portuguesa.

\section{Referências Bibliográficas}

BARRAL, L.M. Notions dur l'île Sainte-Catherine au Brésil, recueillies en 1831 par M. Barral, capitaine de corvette. Annales Maritimes et Coloniales, Paris: Imprimerie Royale, 1(8): 333-345, $2^{\mathrm{e}}$. série, 1833.

BARROW, John. Voyage à la Cochinchine, par les îles de Madère, de Tenerife et du Cap Verd, le Brésil et l'île de Java, contenant des reinsegnements nouveaux et authentiques sur l'État naturel et civil de ces divers pays; Accompagné de la Relation officielle d'un Voyage au Pays des Boushouanas, dans l'intérieur de l'Afrique australe. Trad. Malte-Brun. Paris: F. Buisson, 1807, 2 vv.

Bíblia de Jerusalém. Trad. port. Gustavo da Silva Gorgulho et. al. São Paulo: Paulus, 2004.

COOK, James. The Voyages of Captain James Cook. Illustrated with Maps and Numerous Engravings on Wood. With an Appendix, Giving an Account of the Present Condition of the South Sea Islands, \&c. London: William Smith, 1862. 2 vv.

DEBRET, Jean Baptiste. Voyage Pittoresque et Historique au Brésil, ou Séjour d'un Artiste Français au Brésil, Depuis 1816 jusqu'en 1831 inclusivement, Époques de l'Avénement et de l'Abdication de S.M.D. Pedro $1^{\mathrm{er}}$., Fondateur de 1'Empire Brésilien. Paris: Firmin Didot Frères, 1834-1839. $3 \mathrm{vv.}$

DU PETIT THOUARS, Abel. Voyage autour du monde sur la frégate La Vénus, pendant les années 1836-1839. Publié par ordre du Roi, sous les auspices du ministre de la Marine. Paris: Gide, 1840. 
GINZBURG, Carlo. O alto e o baixo: o tema do conhecimento proibido nos séculos XVI e XVII. In: Mitos, emblemas e sinais: morfologia e história. Trad. port. Federico Carotti. São Paulo: Companhia das Letras, 1989, pp. 95-117.

GOMEZ-GÉRAUD, Marie-Christine. Aux Limites de l'Écriture Viatique, le Récit de Pèlerinage. L'Exemple de de la Description de Jérusalem. In: LINON-CHIPON, Sophie, GUENNOC, JeanFrançois (éds.). Transhumances Divines. Récits de voyage et religion. Paris: Presses de l'Université de Paris-Sorbonne, 2005, pp. 33-42.

HOLANDA, Sérgio Buarque de. Raízes do Brasil. 20. ed. Rio de Janeiro: José Olympio, 1988.

JACKSON, Colonel J.R. What to observe; or the Traveller's Remebrancer. 2. ed. London: Madden and Malcolm, 1845.

KOSTER, Henry. Travels in Brazil. London: Longman, Hurst, Rees, Orme, and Brown, Paternorster-Row, 1816.

LAVOLLÉE, M.C. Voyage en Chine, Ténériffe. - Rio-Janeiro. - Le Cap. - Île Bourbon. Malacca. - Singapore. - Manille. - Macao. - Canton. - Ports Chinois. - Cochinchine. - Java. Paris: Just Rouvier; A. Ledoyen, 1852.

LE DAULT, J.L. Le Para. Province du Brésil dans l'Amazonie. Journal de la Marine, des Colonies, des Consulats et des Voyages. Paris, VIII: 227-232, 1834.

LESTRINGANT, Frank. Le Voyage, Une Affaire de Religion. In: LINON-CHIPON, Sophie, GUENNOC, Jean-François (éds.). Transhumances Divines. Récits de voyage et religion. Paris: Presses de l'Université de Paris-Sorbonne, 2005, pp. 13-31.

LINDLEY, Thomas. Narrative of a Voyage to Brasil; Terminating in the Seizure of a British Vessel, and the Imprisonment of the Author and the Ship Crews, By the Portuguese. With General Sketches of the Country, its Natural Productions, Colonial Inhabitants \&c. and a Description of the City and Provinces of St. Salvador and Porto Seguro. To which are added, A Correct Table of the Latitude and Longitude of the Ports on the Coast of Brasil, Table of Exchange, \&c. London: J. Johnson, 1805.

LUCCOCK, John. Notes on Rio de Janeiro, and the Southern Parts of Brazil; Taken During a Residence of Ten Years in That Country, From 1808 to 1818. London: Samuel Leigh, 1820.

MISSIONARY SOCIETY. A missionary voyage to the Southern Pacific Ocean, performed in the years 1796, 1797, 1798, in the ship Duff, commanded by Captain James Wilson. Compiled from journals of the officers and the missionaries, and Illustrated With Maps, Charts, and Views, Drawn by Mr. William Wilson, and engraved by the most eminent Artists. With a Preliminary Discourse on the Geography and History of the South Sea Islands; And An Appendix, Including Details Never Before Published, of The Natural and Civil State of Otahiti; By a Committee Appointed For the Purpose, By the Directors of Missionary Society. London: T. Chapman, 1799.

NOTHOMB, Amélie. Biographie de la faim. Paris: Albin Michel, 2004.

PAYET-MEURE, Chantale. Robert Challe. La Bible à l'Épreuve du Voyage. In: LINON-CHIPON, Sophie, GUENNOC, Jean-François (éds.). Transhumances Divines. Récits de voyage et religion. Paris: Presses de l'Université de Paris-Sorbonne, 2005, pp. 181-197. 
OUSELEY, William Gore. Descriptions of Views in South America, from Original Drawings, made in Brazil, the River Plate, the Parana, \&c. \&c., With Notes. London: Thomas McLean, 1852.

POPEANGA, Eugenia. El viaje iniciático. Las peregrinaciones, itinerarios, guías y relatos. Revista de Filología Románica. Madrid: Universidad Complutense de Madrid, anejo I: 27-37, 1991.

RACAULT, Jean-Michel. La Preuve par l'Autre, ou du Bon Usage du Paganisme. Theologie de la Revelation Primitive et Comparatisme Religieux Chez Lafitau. In: LINON-CHIPON, Sophie ; GUENNOC, Jean-François (éds.). Transhumances Divines. Récits de voyage et religion. Paris: Presses de l'Université de Paris-Sorbonne, 2005, pp. 145-165.

SAINT-HILAIRE, Auguste de. Voyages dans l'intérieur du Brésil. Première Partie. Voyage dans les Provinces de Rio de Janeiro et de Minas Geraes. Paris: Grimbert et Dorez, 1830. 2 vv.

TENCH, Watkin. A narrative of the Expedition to Botany Bay; with an Account of New South Wales, its Productions, Inhabitants, \&c. To which is Subjoined, A List of the Civil and Military Establishments of Port Jackson. 2. ed. London: J. Debrett, 1789.

TORRÃO FILHO, Amilcar. Narrativas de viagem: cruzamentos de espaços, saberes e temporalidades. Séculos XVIII e XIX. Estudos de História. Franca: Unesp, 12(1): 127-144, 2005.

. A arquitetura da alteridade: a cidade luso-brasileira na literatura de viagem (1783-1845). $\overline{2008}$. Tese (Doutorado em História) - Instituto de Filosofia e Ciências Humanas, Universidade de Campinas, Campinas, 2008.

TUCKER, Josiah. Instructions for Travellers. Dublin: William Watson, 1758.

TURNBULL, John. A Voyage Round the World, in the Years 1800, 1801, 1802, and 1804; in Which the Author visited the principal Islands in the Pacific Ocean, and the English Settlements of Port Jackson and Norfolk Island. London: Richard Phillips, 1805. 3 vv.

VOLNEY, Constantin-François de Chasseboeuf, conde de. Voyage en Syrie et en Egypte pendant les années 1783, 1784 \& 1785. Paris: Volland, 1787. 2 vv.

WHITE, John. Journal of a Voyage to new South Wales with Sixty-five Plates of Non descript Animals, Birds, Lizards, Serpents curious Cones of Trees and other Natural Products. London: J. Debrett, 1790.

WOLFZETTEL, Friedrich. Relato de viaje y estructura mítica. In: ROMERO TOBAR, Leonardo, ALMARCEGUI ELDUYAEN, Patricia (coords.). Los libros de viaje: realidad vivida y género literario. Madrid: Universidad Internacional de Andalucía, Akal, 2005, pp. 10-24.

ZUMTHOR, Paul. Dire le voyage. In: La mésure du Monde. Représentation de l'Espace au Moyen Âge. Paris: Seuil, 1993, pp. 297-316.

\section{NOTAS}

\footnotetext{
${ }^{1}$ Este artigo é resultado de pesquisas realizadas para a minha tese de doutorado intitulada $A$ arquitetura da alteridade: a cidade luso-brasileira na literatura de viagem (1783-1845), defendida em abril de 2008 no Departamento de História da Unicamp.
} 
${ }^{2}$ A referência às escrituras se faz não apenas pela citação, mas também pela "alusão a cenas, personagens e locais bíblicos". Ibid., p.184.

${ }^{3}$ Cf. POPEANGA, 1991; GOMEZ-GÉRAUD, 2005, p.33-42; ZUMTHOR, 1993, p.297-316; e WOLFZETTEL, 2005, p.10- 24.

${ }^{4}$ Imagem bastante parecida da Volney sobre o islã na Síria: para ele, trata-se de um zelo religioso nascido "de um espírito de ciúme e de contradição". "Assim, esta devoção, nascida do orgulho, e acompanhada de uma profunda ignorância, não é mais do que uma superstição fanática, que é a causa de mil desordens” ( VOLNEY, 1787, v. 2, p.421).

Artigo recebido em 03/2010. Aprovado em 06/2010. 